\title{
Time to Blossom: An Inquiry into Bloom's Taxonomy as a Hierarchy and Means for Teaching Legal Research Skills
}

\author{
Paul D. Callister ${ }^{\star *}$
}

Pedagogy requires both a theory and a consistent method of implementation. While the literature of law librarianship abounds in suggestions and descriptions about how legal research is being taught, it lacks sufficient consideration of pedagogical theory from the field of education. In light of the Carnegie Report, and efforts at comprehensive curriculum reform, the time is ripe for law librarianship to develop a comprehensive and properly grounded pedagogy for legal research instruction. This paper proposes and illustrates adapting Bloom's Taxonomy as a means to identify legal research skills, prioritize objectives, and organize course curricula.

Pedagogy — the theory or principles of education; a method of teaching based on such a theory. ${ }^{1}$

\section{Introduction}

I1 Pedagogy includes both a theory and a method "based on such a theory." While the literature in our field boasts considerable description of various methods for teaching legal research, noticeably absent is any theory drawn from leading pedagogues or educational theorists, particularly from outside of law and librarianship. As a result, law librarianship has an overabundance of descriptive literature about teaching methods (mostly, what we do at our respective schools) without significant basis in pedagogical theory. Having built our house without a foundation, the whole structure is suspect.

II2 There never has been a more opportune moment for law librarianship to invest in developing a comprehensive pedagogy for legal research instruction. In

* (C) Paul D. Callister, 2010.

** Director of the Leon E. Bloch Law Library and Associate Professor of Law, University of Missouri-Kansas City, Kansas City, Missouri. I presented this article at the Conference on Legal Information: Scholarship and Teaching, held at the University of Colorado Law School on June 21-22, 2009. It follows my own recently published challenge to the profession to create a Bloom's taxonomy for legal research instruction. See infra note 14. I wish to acknowledge all of the constructive criticism of the participants of the Boulder conference, which helped refine this article. In addition, I must emphatically thank Barbara Bintliff, the law library director at the University of Colorado, for her insights and criticisms, and for persuading me to write again on this important subject.

1. Oxford English Dictionary (Draft Revision Sept. 2009), http://dictionary.oed.com (subscription required for access).

2. $I d$. 
2008, Harvard Law School dedicated an issue of its alumni magazine to "Curriculum Version 2.0." 3 The new curriculum calls for "creative thinking and the ability to draw from a variety of resources in order to solve real-life legal problems of the sort that a lawyer might encounter in practice." 4 These skills are considered necessary in addition to traditional analytical skills. The 2007 Carnegie Foundation report, entitled Educating Lawyers: Preparation for the Profession of Law, also calls for an "integrative model" of legal education stressing as one of its three components "[i]ntroduction to the several facets of practice included under the rubric of lawyering . ..."5 and reiterates the MacCrate Report's call for problem-solving, legal research, and other lawyering skills. ${ }^{6}$ The call for curriculum reform, as now being taken up by Harvard and other schools, should be viewed as a not-to-be missed opportunity for law librarianship to establish its pedagogy, which, optimistically, may embed legal research instruction into current efforts for curriculum reform.

I3 To take advantage of this opportunity for pedagogical development, our profession will need some new attitudes toward scholarship. A new law librarian at the University of Texas, Nolan Wright, recently voiced dismay at the paucity of scholarly discourse on the pedagogy of legal research instruction:

If a newcomer can be so bold, it is the author's impression, based on the literature survey ..., that if librarians want to participate more fully in and make more of a difference in the state of legal research education, then we will need to reconsider some aspects of our professional culture. Specifically, we need to be willing to engage in intellectual dialogue with one another, through peer-reviewed publications, ... and actually discuss and not only cite to each others' scholarship and opinions. ${ }^{7}$

In the words of Mattie Ross, "Hurray to the man from Texas!" 8 May more new librarians have the confidence to speak so frankly.

I4 Wright is right: there has been far too little scholarly engagement on the underlying pedagogy at the heart of legal research instruction. To correct this deficiency, the profession needs to open a dialogue, and this article proposes adapting Bloom's Taxonomy as a common schema for that collaborative effort. ${ }^{9}$

3. Special Section, Curriculum Version 2.0: A New Blueprint for Legal Education, Harv. L. BulL., Winter 2008, at 17-41.

4. Elaine McArdle, A Curriculum of New Realities, Harv. L. Bull., Winter 2008, at 18, 21-22.

5. William M. Sullivan et al., Educating Lawyers: Preparation for the Profession of LaW 194 (2007).

6. Id. at 174; see also Am. Bar Ass'n Section of Legal Educ. \& Admissions to the Bar, Legal Education and Professional Development-An Educational Continuum: Report of the Task Force on Law Schools and the Profession: Narrowing the Gap 138-40 (1992) (MacCrate Report). "It can hardly be doubted that the ability to do legal research is one of the skills that any competent legal practitioner must possess." Id. at 163. But see Richard A. Leiter, The Missing Lawyering Skill, AALL SPECTRUM, July 2008, at 22, 22. ("[L] egal research instruction gets almost no mention anywhere in [Educating Lawyers]. There is not a single reference to legal research in the index. Legal research is rarely mentioned as a lawyering skill.")

7. Nolan L. Wright, Standing at the Gates: A New Law Librarian Wonders About the Future Role of the Profession in Legal Research Education, 27 Legal Reference Services Q. 305, 306-07 (2008).

8. TRUe GRIT (Paramount Pictures 1969).

9. A schema is an "organized representation of things or events that guide a person's thoughts and actions." See Types of Thinking: Expert and Novice Thinking, Encyclopædia Britannica Online, http://www.search.eb.com/eb/article-275929 (last visited Apr. 1, 2010) (subscription required for 
I5 In this article, I briefly review the literature from law librarianship and legal education on pedagogy and research instruction, and then present Bloom's taxonomy, borrowing from the field of education. I adapt the taxonomy, as a minimal schema, to order legal research skills. Finally, I present a comprehensive illustration of how the taxonomy might be applied in instructional design to suggest and organize learning activities and assessment. I conclude, much as Wright began, by calling upon the profession to engage in a collective effort to establish a common pedagogy, based upon sound educational theory.

\section{A Search for Pedagogy-A Brief Review of the Literature}

I6 In the spirit of scholarly exchange, I must return to Wright, and like him, look for evidence of scholarly development of pedagogy within the profession. Wright correctly identifies the only notable serious exchange on pedagogy as that surrounding the Wrens vs. Berring and Vanden Heuvel debates, which took place in the late 1980s. ${ }^{10}$ As a new librarian, I had reviewed the debates in detail in $2003 .{ }^{11}$ At that time, and with the bright-eyed enthusiasm of the newly-converted librarian, I presumed to call upon the profession to engage in more meaningful discussion. However, according to Wright, "few have taken up [the] call and responded in scholarly writings of their own.... [, illustrating] the basis for this author's concern about the lack of publicly aired scholarly dialogue within the profession, let alone between the profession and other disciplines." ${ }^{2}$ The lack of dialogue has contributed to the failure to establish a pedagogy grounded both in educational theory and a methodology based upon such theory.

I7 Beyond a lack of dialogue on the subject, others have noticed the failure to develop a serious pedagogy. ${ }^{13}$ True, AALL has produced Core Legal Research

access). In this instance, Bloom's taxonomy is a schema that can guide legal research instructors to teach and assess common sets of skills. Throughout this article, I use the term the technical term "schema," or "schemata" for the plural, but I mean it in the broadest sense to include mental construct, conceptual framework, paradigm, taxonomy, and heuristic.

10. For the uninitiated, the debate consisted of a series of exchanges following the publication of an initial article by the Wrens in 1988. See Christopher G. Wren \& Jill Robinson Wren, The Teaching of Legal Research, 80 LAW LibR. J. 7 (1988) [hereinafter Wren \& Wren, Teaching of Legal Research]; Robert C. Berring \& Kathleen Vanden Heuvel, Legal Research: Should Students Learn It or Wing It? 81 LAW LiBR. J. 431 (1989) [hereinafter Berring \& Vanden Heuvel, Learn It or Wing It?]; Christopher G. Wren \& Jill Robinson Wren, Reviving Legal Research: A Reply to Berring and Vanden Heuvel, 82 LAW LiBR. J. 463 (1990); Robert C. Berring \& Kathleen Vanden Heuvel, Legal Research: A Final Response, 82 LAW LiBR. J. 495, 495 (1990). See also Wright, supra note 7, at 320-23 (reviewing the debate).

11. Paul Douglas Callister, Beyond Training: Law Librarianship's Quest for the Pedagogy of Legal Research Education, 95 LAW LiBr. J. 7, 11-22, 2003 LAW LiBr. J. 1, III 8-33.

12. Wright, supra note 7 , at 322-23.

13. Maureen F. Fitzgerald, What's Wrong with Legal Research and Writing? Problems and Solutions, 88 LAW LIBR. J. 247, 271 (1996) ("It has been suggested that part of the reason skills have been slow to enter the school curriculum is the lack of theory-based research on skills."); Julie Macfarlane, Look Before You Leap: Knowledge and Learning in Legal Skills Education, 19 J.L. \& Soc'y 293, 294 (1992) (“An unfortunate dimension of the current context of curriculum change is the serious dearth of theoretical (rather than purely descriptive) literature in this area"). 
Competencies. ${ }^{14}$ It is a weighty and detailed document, identifying everything a lawyer should know about legal resources and how to use them. The intent behind the document was to respond to the MacCrate Report by articulating the knowledge, skills, and values necessary to do legal research. While valuable for other reasons, Core Legal Research Competencies does not offer a comprehensive pedagogy for guidance to instructors because it proffers neither theory nor methodology for instruction or learning. Rather, Core Legal Research Competencies is a comprehensive bibliography of resources. In fairness, it serves a different purpose, articulating what attorneys should know about research resources. ${ }^{15}$

I8 But what is the underlying evidence, beyond subjective opinion, that law librarianship's literature lacks sufficient scholarly depth with respect to pedagogical theory? It is time to look more closely at our scholarly literature.

I9 Of the twenty-five articles listed in The Essential Law Library Journal, four address how to teach legal research. ${ }^{16}$ The first article, by Fredrick Hicks, describes how legal bibliography is taught at Columbia, but without reference to any theoretical pedagogy. ${ }^{17}$ The second, by Theodore Potter, challenges a list of assumptions

14. Research Instruction Caucus, Am. Ass'n of LaW Libraries, Core Legal Research Competencies: A Compendium of Skills and Values as Defined in the ABA's MacCrate Report (Ellen M. Callinan ed., 1997), available at http://www.aallnet.org/sis/ripssis/PDFs/core.pdf [hereinafter Core Legal Research Competencies].

In August of 2009, subsequent to the presentation of this article at the Boulder conference, the American Association of Law Libraries (AALL) formed a Joint Committee on Articulation of Law Student Information Literacy. On Oct. 7, 2009, the committee released draft standards for comment among the Academic Law Libraries Special Interest Section (ALL-SIS) and also submitted them to AALL's Executive Board. See E-mail from Kumar Percy Jayasuriya, Member, AALL Joint Committee on Articulation of Law Student Information Literacy, to ALL-SIS listserv (Oct. 6, 2009, 1:22 PM CST) (on file with author). While subject to limited distribution, and not ready for formal citation, these draft standards are generally organized around (1) identifying appropriate resources, (2) accessing appropriate information, (3) evaluating information and its sources, (4) applying the information effectively, and (5) understanding relevant ethical issues pertaining to research. These standards track a statement produced by the Boulder conference. See The Boulder Statement on Legal Research Education, posting of Joe Hodnicki to Law Librarian Blog, http://lawprofessors.typepad .com/law_librarian_blog/2009/08/the-boulder-statement-on-legal-research-education.html (Aug.25, 2009). While the Joint Committee's draft standards are a significant step forward, unlike the Boulder Statement and the approach taken in this article, the committee focuses on information resources and strategies, rather than also giving due consideration to the analysis of the research problems themselves, and the higher-level thinking skills that accompany such analysis. See Paul D. Callister, Thinking Like a Research Expert: Schemata for Teaching Complex Problem-Solving Skills, 28 LEGAL REFERENCE SERVICES Q. 31 (2009) (illustrating the need for teaching higher-level thinking skills).

15. Core Legal Research Competencies, supra note 14, at 15 ("To determine if a decision has been effected (sic) by judicial action, a competent lawyer should know that Shepard's Citations provide access to case currency."); 24 ("Every lawyer should be familiar with the distinctions between the session laws passed by legislatures and the codified version of those session laws."); 51 ("The lawyer should know the precedential value of administrative materials ...."); 101 ("The competent lawyer should be able to exercise judgment in choosing manual or electronic tools ....").

16. Frank G. Houdek, The Essential Law Library Journal, 100 LAW Libr. J. 137, 2008 LAW Libr. J. 6.

17. Frederick C. Hicks, Instruction in Legal Bibliography at Columbia University Law School, 9 LAW LiBr. J. 121 (1916). 
about teaching print first. ${ }^{18}$ His arguments are largely based upon practical experience and the changing information environment.

I10 The last two of the four articles from The Essential Law Library Journal that are relevant to legal research instruction, the Wren vs. Berring and Vanden Heuvel articles, do get to pedagogy. The Wrens articulated the need to contextualize instruction and utilize frameworks. ${ }^{19}$ They did this under a heading entitled, "Joining the Academic Mainstream," referring to legal academia, and by arguing: "Legal research instruction lends itself as readily as any substantive law course to using functional frameworks analogous to those that make other law school courses effective ...." ${ }^{20}$ Rather than directly connecting their methods to pedagogical theory from the field of education, the Wrens proposed teaching legal research courses more like substantive law courses, and recognized the need for conceptual frameworks. The closest the Wrens came to grounding their ideas in pedagogical theory was to cite Robert Redmount's A Conceptual View of Legal Education. ${ }^{21}$ Redmount's article is built upon solid pedagogical theory, ${ }^{22}$ but its connection to our field through the Wrens is fairly minimal and attenuated. The last of the four articles from The Essential Law Library Journal, Berring and Vanden Heuval's article, ${ }^{23}$ includes a robust defense of Hicks, ${ }^{24}$ and a valuable description of their own work. ${ }^{25}$ Nonetheless, my review of their thoughtful article does not reveal a deep connection to pedagogical theory beyond their own practical experience and a restatement of Hicks.

I11 Other than the "essential" reading list, there are a few notable exceptions in the literature that do more than tangentially address pedagogy. Those that do are chiefly concerned with "learning styles." 26 While consideration of learning styles is important, it is not the whole of pedagogy.

18. Theodore A. Potter, A New Twist on an Old Plot: Legal Research is a Strategy, Not a Format, 92 LAW LiBR. J. 287, 2000 LAW LiBR. J. 25.

19. See Wren \& Wren, Teaching of Legal Research, supra note 10, at 20.

20. Id. at 24 .

21. Wren \& Wren, Teaching of Legal Research, supra note 10, at 18 n.34 (“'Learnability' requires that subject matter material conform to properties of logic and intellect. This means that form, sequence and organization are important in each of the complexes of materials to be observed." (quoting Robert S. Redmount, A Conceptual View of Legal Education, 24 J. Legal Educ. 129, 140 (1971-1972))). The Wrens also cite Thomas Kuhn for support of the need for paradigms (schema) as a condition of perception. Id. at $55 \mathrm{n} .156$ (citing Thomas Kuhn, The Structure of Scientific Revolutions 113 (2d ed. 1970)). However, Kuhn was really a scientific historian, rather than a pedagogue. See Kuhn, Thomas S., 7 The New EnCyclopædia Britannica 27 (15th ed. 2007).

22. See Redmount, supra note 21, at 130 n.3 (citing educational philosopher, Mortimer Adler); 131-32 nn.4-7 (citing Dewey, Locke, Piaget, and Bruner, Goodnow, and Austin).

23. Berring \& Vanden Heuvel, Learn It or Wing It?, supra note 10.

24. Id. at $432-37$.

25. Id. at $441-48$.

26. See, e.g., Eileen B. Cohen, Teaching Legal Research to a Diverse Student Body, 85 LaW Libr. J. 583 (1993). However, Professor Cohen acknowledges:

Surprisingly ... few articles in the law library literature discuss improving teaching methods by incorporating an understanding of the different learning styles of students. One article presents several learning styles and provides a broad overview of the application of these modes to teaching in general. No article addresses differences in learning styles of students in the increasingly diverse student population as a method of improving the teaching of legal research. 
\$12 Perhaps evidencing the largest gap in our scholarly literature is the scant mention of prominent figures in pedagogy, particularly instructional design theorists such as Benjamin Bloom, Jerome Bruner, Malcolm S. Knowles, David A. Kolb, Seymour Papert, Jean Piaget, and Lev S. Vygotsky. Table 1 illustrates the omission of such figures in articles from Law Library Journal, compared to important journals in legal research and writing and general librarianship. ${ }^{27}$

$\mathbb{1 1 3}$ Counting citations is not an exact indicator of the level of penetration of pedagogical theory into any field; however, looking at the comparative numbers, and based on the meager nine citations in Law Library Journal, suspicions are justified that our field has paid little serious attention to pedagogical theory and its luminaries. ${ }^{28}$ It is not a competition, but the fact that we significantly trail our colleagues both in legal writing and more general academic librarianship should serve as motivation to try harder to incorporate sound pedagogical theory.

\section{Bloom's Taxonomy: An Overview}

I14 Because Bloom is perhaps the most cited pedagogical theorist, per table 1, it is appropriate to focus on him, at least as a start, in an effort to incorporate his pedagogy into the field. In 1996, Canadian law librarian Maureen Fitzgerald was

Id. at 585 (citing David W. Champagne, Improving Your Teaching: How Do Students Learn?, 83 LAW LIB. J. 85 (1991)). The other prominent exceptions are a pair of recent articles by Kristin Gerdy, who, in addition to discussing learning types, also explored the "learning cycle." Kristin B. Gerdy, Teacher, Coach, Cheerleader, and Judge: Promoting Learning through Learner-Centered Assessment, 94 LAW LIBR. J. 59, 2002 Law LiBr. J. 4 [hereinafter Gerdy, Teacher, Coach, Cheerleader, and Judge]; Kristin B. Gerdy, Making the Connection: Learning Style Theory and the Legal Research Curriculum, LEGAL REFERENCE SERVICES Q., vol. 19, nos. 3-4, at 71 (2001). For a few other possible exceptions, see generally Terry Jean Seligmann, Beyond "Bingo!": Educating Legal Researchers as Problem Solvers, 26 WM. MITCHELL L. REv. 179 (2000) (discussing qualities of successful researchers and ways to cultivate those traits); Robin A. Boyle \& Rita Dunn, Teaching Law Students Through Individual Learning Styles, 62 AlB. L. ReV. 213 (1998) (addressing legal instruction in general); Jane Thompson, Teaching Research to Faculty: Accommodating Cultural and Learning-Style Differences, 88 LAW LiBR. J. 280 (1996) (discussing law school faculty only); Vernellia R. Randall, The Meyers-Briggs Type Indicator, First Year Law Students and Performance, 26 CuMB. L. Rev. 63 (1995) (addressing legal instruction in general).

27. The names were selected after initially consulting lists of prominent theorists in articles in the journals Pedagogy, Philosophy of Education, and Instructional Design. Generally, I only included more recent theorists and those for whom information could be found in the journals selected for inclusion in Table 1. The names were also selected because they tended to resurface with some regularity.

The citation counts were compiled by searching HeinOnline (for Law Library Journal and the Journal of Legal Education), Westlaw (for Legal Writing) and WilsonWeb (for the Journal of Academic Librarianship, Teacher Librarian, College \& Research Libraries, and the combined database of All Library and Information Science Literature). Unfortunately, I found no full-text database for Legal Reference Services Quarterly. I searched for various combinations of the educational theorists' names; my search for Bloom looked for both Benjamin /3 Bloom and Bloom! and Taxonomy in Westlaw.

28. Among the exceptions are Sunil Rao, Making Sense of Making Stories: Law, Literature, Life, 95 LaW Libr. J. 455, 2003 LAW Libr. J. 34 (reviewing Jerome Bruner, Making Stories: LaW, Literature, Life (2002)); Peter A. Hook, Creating an Online Tutorial and Pathfinder, 94 LAW LiBr. J. 243, 255 n.65, 2002 LAw LiBr. J. 18, II 40 n.65 (citing Bloom to explain his instructional design choices for online tutorials); Gerdy, Teacher, Coach, Cheerleader, and Judge, supra note 26, at 62, II 10 (referring to Piaget, as well as other significant pedagogues not included in Table 1-John Dewey, Kurt Lewin, and David Kolb); Fitzgerald, supra note 13, at 262 (discussing Benjamin Bloom's taxonomy). 
Table 1

Number of Articles Citing Key Pedagogues

\begin{tabular}{|c|c|c|c|c|c|c|c|}
\hline & 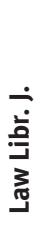 & 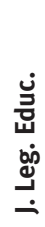 & 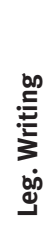 & 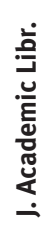 & 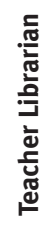 & 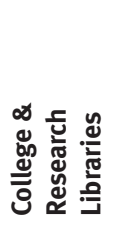 & 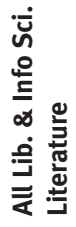 \\
\hline Benjamin Bloom & 2 & 8 & 3 & 8 & 10 & 11 & 151 \\
\hline Jerome Bruner & 1 & 8 & 13 & 1 & 0 & 1 & 28 \\
\hline Malcolm S. Knowles & 1 & 5 & 2 & 3 & 0 & 2 & 17 \\
\hline David A. Kolb & 2 & 9 & 2 & 3 & 0 & 2 & 16 \\
\hline Seymour Papert & 1 & 0 & 0 & 0 & 3 & 0 & 18 \\
\hline Jean Piaget & 2 & 1 & 5 & 1 & 6 & 2 & 122 \\
\hline Lev S. Vygotsky & 0 & 5 & 4 & 2 & 5 & 1 & 21 \\
\hline Total & 9 & 36 & 29 & 18 & 24 & 19 & 373 \\
\hline
\end{tabular}

the first to identify Bloom's taxonomy as a theoretical basis for legal research instruction. ${ }^{29}$ Fitzgerald credited Bloom with distinguishing types of learning (not to be mistaken with learning styles) and calling for different teaching methods for each learning type. ${ }^{30}$ Sadly, although Fitzgerald's article is cited elsewhere, it has never been cited in Law Library Journal. This is not an indictment of Fitzgerald's work, which is excellent, but of our failure as a profession to engage in productive dialogue and take our own scholarship seriously.

$\mathbb{1 1 5}$ Bloom’s Taxonomy of Educational Objectives ${ }^{31}$ has been illustrated in terms of three domains with progressively ranked orders of types of learning. An illustration of a single domain - the cognitive domain - is set forth in figure 1 .

\$16 This schema divides learning activities into six classes and identifies instructional activities that meet each class's objective. The learning activities are ranked in increasing sophistication as one moves around the inner six-point star at the center of the rose-from 1 (knowledge) to 6 (evaluation). Note that the words around the star of the rose, in the hexagon, are all verbs, and the words in the outer circle are all nouns. The model is set up by correlating types of learning to action verbs and to nouns describing outcomes. ${ }^{32}$ Thus, recognizing, describing, and locat-

29. Fitzgerald, supra note 13, at 162.

30. Id.

31. Taxonomy of Educational Objectives: The Classification of Educational Goals; Handbook 1: Cognitive Domain (Benjamin S. Bloom ed., 1956).

32. Unlike the rose in figure 1, Bloom's Taxonomy of Educational Objectives does not correlate hierarchies of activities to action verbs and descriptive nouns; instead, descriptions of classes of educational objectives correlate to lists of specific educational objectives and illustrations. See id. at 44. It also does not couch educational objectives as "learning in action." It is important to note that Bloom's taxonomy is not predicated upon "active learning theory," which has been rendered suspect by the 


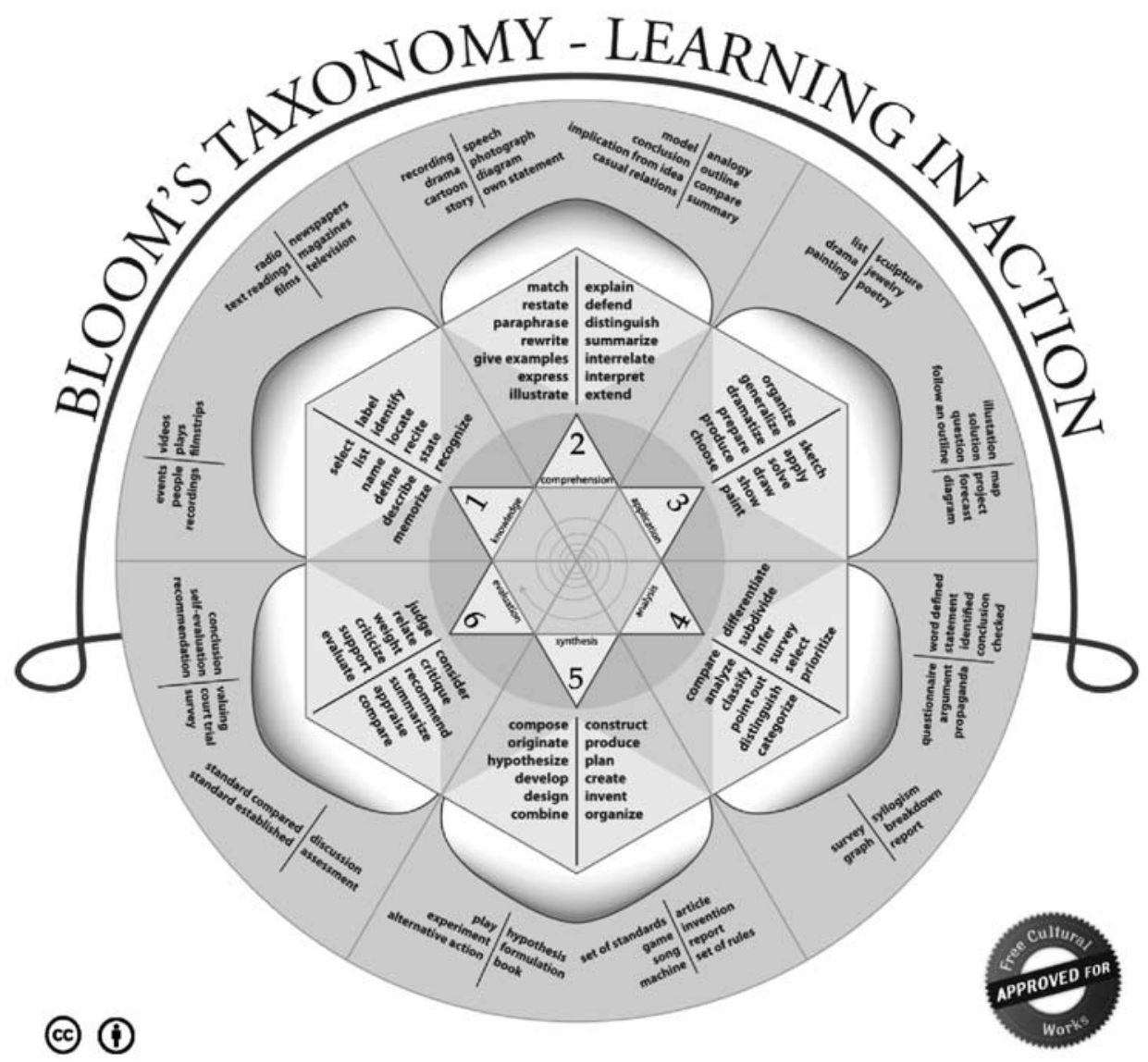

Figure 1. Bloom's Taxonomy (Cognitive Domain Only)

Source: K. Aainsqatsi, Wikipedia, File: Blooms Rose.svg, http://en.wikipedia.org/wiki/File:Blooms_rose .svg (last visited Feb. 22, 2010). Image is licensed under Creative Commons License BY 2.5. For terms of license, see http://creativecommons.org/licenses/by/2.5/.

ing American Law Reports are the actions used for acquiring basic knowledge of an important legal resource. Using the outer petal in the figure, these actions could be taught in a variety of ways - textual readings (such as a scripted tour of the library) or a video highlighting important legal resources. Furthermore, the ability to recognize, describe, and locate American Law Reports is something that can be measured. Acquiring knowledge about basic legal resources is a first-order objective in Bloom's model.

I17 As Bloom's model moves progressively through more difficult types of learning, acquiring knowledge is followed by comprehension, requiring actions such as matching, explaining, and summarizing, perhaps resulting in explaining that

significant criticism it has received. See, e.g., Paul A. Kirschner et al., Why Minimal Guidance During Instruction Does Not Work: An Analysis of the Failure of Constructivist, Discovery, Problem-Based, Experiential, and Inquiry-Based Teaching, 41 EduCATIONAL Psychologist 75 (2006). 
American Law Reports is a "combined resource" containing case reports (primary authority), commentary (secondary authority), and annotations. Eventually, one makes one's way around the rose petals through application, analysis, and synthesis to evaluation, which requires actions like judgment, criticism, evaluation, and assessment. For example, evaluation might be measured by assessing whether use of the American Law Reports had been an effective starting place for researching a particular tax problem. The point is that the types of learning are arranged in a hierarchy of progressive difficulty and importance. Often, only the lowest order types of learning are engaged in educational programs. ${ }^{33}$

\section{An Adapted Bloom's Taxonomy for Legal Research}

I18 To present a beginning point for constructing a model for the field of legal research instruction, I have adapted Bloom's model as shown in figure 2. My Adapted Taxonomy lacks the detail of the original in figure 1. This simplifies discussion and encourages readers to fill in the Adapted Taxonomy with greater detail of their own. In addition, I have included a blank version of the Bloom's Taxonomy as an appendix so that readers may construct their own taxonomies from scratch.

\section{Remembering}

\$19 In 2002, David Krathwohl suggested a revision of Bloom's Taxonomy and renamed Knowledge in Bloom's original taxonomy to Remember. ${ }^{34}$ Krathwohl includes recognizing and recalling as part of his taxonomy. The two versions, as presented by Krathwohl, are shown in table $2 .{ }^{35}$ In my Adapted Taxonomy, remembering is described as recognizing. However, recalling could be added, as could the other elements of Bloom's original taxonomy (1.10-1.32 in the left column of table 2).

I20 In the Adapted Taxonomy, the verb Recognize is served by the objects problems, paradigms, and terms. Recognizing that there is an information problem or deficit is essential to professional standards for information literacy. ${ }^{36}$ This is not as simple as it may seem. Understanding what we don't know, versus what we do know, is not always readily apparent. It is such an important issue that a favorite college philosophy professor of mine once commenced a course by asking, "What

33. See College Science Teachers Guide to Assessment 36 (Thomas R. Lord et al. eds., 2009) (80-90\% of college science tests involve lower-order questions).

34. David R. Krathwohl, A Revision of Bloom's Taxonomy: An Overview, 41 TheOry INTO PraCtiCE 212, 214 (2002).

35. Id. at 213 tbl.1 (left column); 215 tbl.3 (right column).

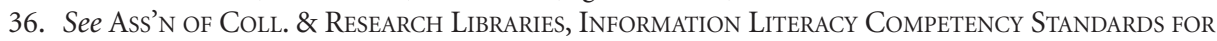
Higher EDUCATION 2 (2000), available at http://www.ala.org/ala/mgrps/divs/acrl/standards/standards .pdf. "Information literacy is a set of abilities requiring individuals to 'recognize when information is needed and have the ability to locate, evaluate, and use effectively the needed information." Id. (quoting Presidential Comm. On Info. Literacy, Am. Library Ass'N, FinAl Report (1989), http://www.ala .org/ala/mgrps/divs/acrl/publications/whitepapers/presidential.cfm). For recent developments, see the discussion of AALL's Joint Committee on the Articulation of Law Student Information Literacy Standards, supra note 14. 


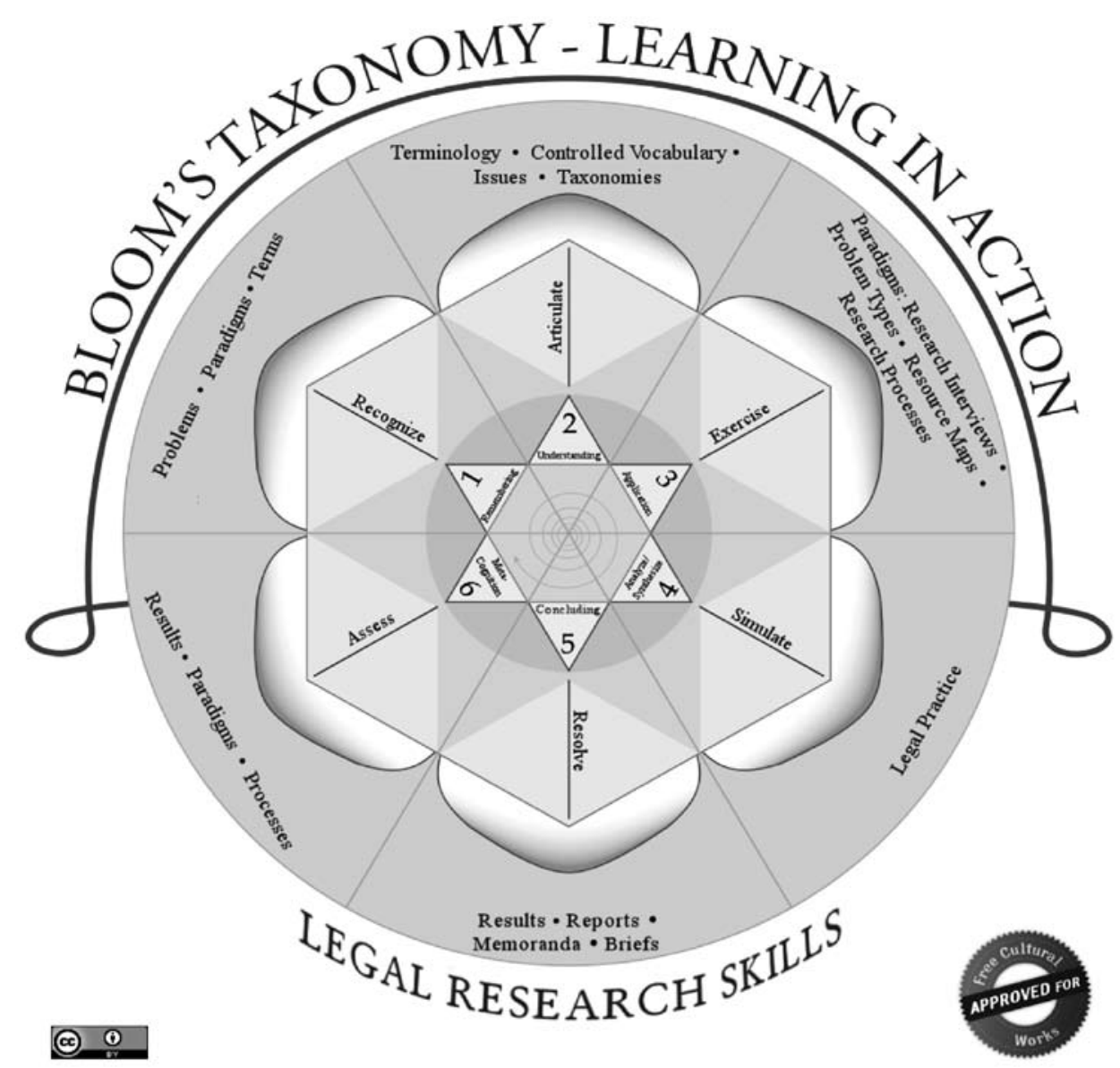

Figure 2. An adaptation of Bloom's Taxonomy for legal research skills [hereinafter Adapted Taxonomy].

Image is licensed under the same terms and conditions as the original as updated by Creative Commons License BY 3.o. For terms of license, see http://creativecommons.org/licenses/by/3.o.

is a good question?" 37 We spent the entire class on the subject. My professor's answer was that a good question is always on the edge of what an individual knows - on the edge of one's construct (or schema) of reality. To be able to see that edge - to recognize when one is approaching it - is the beginning of all inquiry and a necessary skill.

I21 This emphasis on recognizing an information deficiency finds sound basis in a theory known as constructivism, which posits that rather than being simply based upon conscious experience, knowledge is based on constructs, relational variables, or cognitive mental structures that serve as aids "in making sense of the immensely complicated network of associations between stimulus conditions and

37. Author's recollection of Professor Chauncey C. Riddle's opening remarks to an honor's philosophy seminar taught at Brigham Young University in winter 1986 (originally discussed in Callister, supra note 11 , at 34$)$. 


\section{Table 2}

\section{Bloom's Taxonomy (left), Krathwohl's Revised Taxonomy (right)}

\section{Structure of the Original Taxonomy}

1.o Knowledge

1.10 Knowledge of specifics

1.11 Knowledge of terminology

1.12 Knowledge of specific facts

1.20 Knowledge of ways and means of dealing with specifics

1.21 Knowledge of conventions

1.22 Knowledge of classifications and categories

1.24 Knowledge of criteria

1.25 Knowledge of methodology

1.30 Knowledge of universals and abstractions in a field

1.31 Knowledge of principles and generalizations

1.32 Knowledge of theories and structures

2.0 Comprehension

2.1 Translation

2.2 Interpretation

2.3 Extrapolation

3.0 Application

4.0 Analysis

4.1 Analysis of elements

4.2 Analysis of relationships

4.3 Analysis of organizational principles

5.0 Synthesis

5.1 Production of unique communication

5.2 Production of a plan, or proposed set of Operations

5.3 Derivation of a set of abstract relations 6.0 Evaluation

6.1 Evaluation in terms of internal evidence

6.2 Judgments in terms of external criteria

\section{Structure of the Cognitive Process Dimension of the Revised Taxonomy}

1.o Remember-Retrieving relevant knowledge from long term memory.

1.1 Recognizing

1.2 Recalling

2.o Understand-Determining the meaning of instructional messages, including oral, written, and graphic communication.

2.1 Interpreting

2.2 Exemplifying

2.3 Classifying

2.4 Summarizing

2.5 Inferring

2.6 Comparing

2.7 Explaining

3.o Apply-Carrying out or using a procedure in a given situation

3.1 Executing

3.2 Implementing

4.0 Analyze-Breaking material into its constituent parts and detecting how the parts relate to one another and to an overall structure or purpose.

4.1 Differentiating

4.2 Organizing

4.3 Attributing

5.o Evaluate-Making judgments based on criteria and standards.

5.1 Checking

5.2 Critiquing

6.o Create-Putting elements together to form a novel, coherent whole or make an original product.

6.1 Generating

6.2 Planning

6.3 Producing 
responses ...." ${ }^{38}$ Moving from knowledge to learning, "the contemporary view of learning is that people construct new knowledge and understandings based on what they already know and believe ...." The real issue is "the incomplete understandings, the false beliefs, and the naive renditions of concepts that learners bring with them to a given subject." 40 The skill of understanding when one's knowledge constructs (or schemata) are inadequate, and thus to recognize the need for research, is an important initial step or rung in the hierarchy of skills necessary to become an expert legal researcher.

I22 To illustrate, suppose that a new associate, Loraine, is asked to form a Missouri limited liability company (LLC) for a client. While Loraine successfully locates an operating agreement for a "member-managed" LLC in the firm's files and the Missouri's registration web site for LLCs in her state, she fails to understand the issues surrounding formation of LLCs and that there are alternatives to "member-managed" LLCs that include management structures that look more like general partnerships or corporations. Loraine also does not know about many of the issues, such as buyouts, single member LLCs, securities registration, and professional planning. What Loraine failed to do is research checklists for business organizations, including LLCs in Missouri and other states. She was unsuccessful in recognizing the important border of what she knew and did not know and that she had an information deficit.

\section{Understanding}

I23 With respect to the second type of learning, I have used Krathwohl's term Understanding, but described it, in verb form, as Articulate, suggesting the ability to define, explain, outline, and exemplify research concepts, paradigms (schemata), and issues. Of particular importance is the mastery of technical language, controlled vocabularies, and taxonomies.

$\mathbb{I 2 4}$ For instance, precision and recall are useful concepts from the library and information sciences, which can help students understand some of the pitfalls of electronic research. Besides recalling the formula for each, ${ }^{41}$ can the student explain

38. Thought and Thought Processes, 28 The New EnCYCLOPÆDIA BRITANNICA, supra note 21, at 650. However, constructivism also has come to be associated with educational theories espousing minimal guidance or instruction. See, e.g., Joe Becker \& Maria Varelas, Assisting Construction: The Role of the Teacher in Assisting the Learner's Construction of Preexisting Cultural Knowledge, in CONSTRUCTIVISM IN EDUCATION 433 (Leslie P. Steffe \& Jerry Gale eds., 1995) (describing constructivism and modifying it further to help students establish social norms). "The emphasis on learners' need to construct their own knowledge has led, in part, to replacing a 'transmission' approach to education with a 'discovery' approach." Id. at 434. But see Kirschner et al., supra note 32 (criticizing this approach).

39. How People Learn: Brain, Mind, Experience, and School 10 (John D. Bransford et al. eds., 1999).

40. Id.

41. Precision is the ratio relevancy in search results and is expressed:

$\left(\frac{\text { Number of Relevant Documents Retrieved }}{\text { Total Number of Documents Retrieved }}\right) \times 100$

Recall reveals what is missed in a search and is defined as:

$($ Total Number of Relevant Documents in the Collection $) \times$ 
that precision measures the relevancy of results from a search, but recall measures what was missed?

I25 As another example, can the student produce the schema shown in table $3^{42}$ and explain it? If the student can understand and explain the underlying doubletripartite organization of law based upon branches of government and chronological, topical, and "citational" arrangements, he or she has mastered the skill. If the student has the cognitive ability to think about the law in this arrangement, he or she has moved beyond simply remembering a schema to its articulation.

\section{Table 3}

Adaptation of Wren Schema

\begin{tabular}{lllll}
\hline Institution & Kind of Law & \multicolumn{2}{c}{ How the Law is Published (Arrangements) } \\
Legislature & Statutory Law & $\begin{array}{l}\text { Chronologically } \\
\text { Session Laws }\end{array}$ & $\begin{array}{l}\text { Topically } \\
\text { Statutory Codes }\end{array}$ & $\begin{array}{l}\text { By Citation } \\
\text { Shepard's, KeyCite, } \\
\text { Annotated Codes }\end{array}$ \\
Courts & Case Law & Case Reports & $\begin{array}{l}\text { Case Digests } \\
\text { (Summaries of } \\
\text { Primary Authority) }\end{array}$ & $\begin{array}{l}\text { Shepard's, KeyCite, } \\
\text { ALR }\end{array}$ \\
$\begin{array}{l}\text { Agencies and } \\
\begin{array}{l}\text { Executive } \\
\text { Branch }\end{array}\end{array}$ & Administrative Law & $\begin{array}{l}\text { Administrative } \\
\text { Registers or }\end{array}$ & $\begin{array}{l}\text { Administrative } \\
\text { Codes }\end{array}$ & $\begin{array}{l}\text { Shepard's, KeyCite, } \\
\text { Annotated Codes }\end{array}$ \\
\hline
\end{tabular}

\section{Application}

I26 Application as a skill is learned through exercise. By exercising students in various schemata-including schemata for research interviews, ${ }^{43}$ problem typing, ${ }^{44}$ resource maps ${ }^{45}$ and the research process ${ }^{46}$ — students form the necessary cognitive patterns or habits to quickly solve problems and think like attorneys and expert researchers. Table 4 breaks down problems into their respective types, a helpful aid if students are to learn to differentiate problems and the types of resources that match those problem types. ${ }^{47}$

F. W. Lancaster, Precision and Recall, in 2 ENCYCLOPEDIA OF LibraRY AND INFOrMation SCIENCE 2346, 2346 (Marcia J. Bates et al eds., 2d ed. 2003).

42. This schema is an adaptation of that used by the Wrens in The Teaching of Legal Research. Wren \& Wren, Teaching of Legal Research, supra note 10, at 35, matrix A. My adaptation of it previously appeared in Callister, supra note 14, at 40 tbl.4.

43. See infra II 29.

44. See infra table 4.

45. See supra table 3.

46. See infra figure 6.

47. For the original schema, used for government documents, see Jean L. Sears \& Marilyn K. Moody, Using Government Information Sources: Electronic and Print 5-9 (3d ed. 2001). My adaptation of the schema originally appeared in Callister, supra note 14, at 37. 
Table 4

Problem Typing

Search Type

Known Item

Subject

Institutional

Statistical

Special Techniques

News

Reference
Used For

I already know the citation, case name, name of an act, or have a very specific fact pattern to research.

I am not looking for a specific item but for information on a particular subject.

I know what I am looking for will be found at a particular institution, agency, or organization, or I want to find out which agency administers a particular program or enforces a particular law.

I need statistical information from a government or other trustworthy source.

I am searching for materials that require special interpretive or interdisciplinary skills.

\section{Example}

Where do I find Roe v. Wade?

I need the California murder case in which the court found that a fetus cannot be a human being and the defendant was acquitted of murder after beating up his girlfriend, resulting in the loss of the fetus.

I am looking for something explaining ERISA generally, including what kind of retirement plans it covers.

I need to understand exemptions from creditors in California.

I need Department of Justice rulings and opinion letters on when the merger of two large medical groups falls within the safe harbor provisions for antitrust issues. I need any Department of Labor rulings regarding the "anti-alienation” provisions of ERISA.

I need to know the percentage of children living below the poverty level in Los Angeles.

I need legislative history and current legislation and regulatory action; budget, patent, census, and historical materials; government documents; international and foreign law; tax forms and IRS materials; scientific and technical reports; public records; or competitive business intelligence.

I need the legislative history of the ERISA anti-alienation provisions.

I am searching for news stories.

I need accounts of the lawsuit against Yahoo in France by a humanitarian group.

I need to know the etymology of "escrow."

I don't even know what "fair use" is. 


\section{Analysis and Synthesis}

I27 Again, I have modified both Bloom's Taxonomy and Krathwohl's revision by collapsing Analysis and Synthesis into a single class. They could be broken out again, with seven orders to the taxonomy, but I prefer to engage in the two activities together in a reiterative process.

I28 Analysis is defined as: "The resolution or breaking up of anything complex into its various simple elements, the opposite process to synthesis; the exact determination of the elements or components of anything complex . . ."48 The essence of the concept, as applied to the taxonomy, is determining the elements of a problem. Coming from yet another taxonomy of learning skills, analysis is described as the "ability to restructure the problem situation." ${ }^{49}$ In sum, analysis requires the separation, identification, and reordering of elements for research problems encountered in legal practice.

I29 To illustrate analysis, consider the steps an attorney might take when faced with the complex problem shown in figure 3. First, the attorney needs to consider what are the terms that describe factual and legal issues and the general topics for research. Dissection and organization of parts is what constitutes analysis.

You are counsel for the University of Missouri. Beginning in 2005, a faculty member commenced work on a comprehensive tutorial, illustrating online research skills. Using several hundred screenshots, the tutorial walks students through comparative uses and features for two online legal research services. Arrows and comments are superimposed on the shots to help students follow what is happening.

The faculty member offers her work for free to the University of Missouri, but she would like to license the tutorial for profit to other institutions. Concern has been raised about whether the screenshots constitute "fair use" under the copyright Act. Furthermore, while university legal counsel was careful to preserve "fair use" rights by explicit reference in each of the licenses, both services incorporate "click buttons" at their sign-on screens for the end user to indicate acceptance of "terms of use." These terms can be displayed with a hyperlink and are different than those agreed to by the university. They strictly limit uses to an enumerated list. The use of screenshots is not listed among the permissible uses, nor are there any references to "fair use." The "end-user" licenses indicate that Virginia law applies, but the licenses with the university specify Missouri law. The end-user agreements are incorporated by reference into the agreements between the university and the vendor.

May the faculty member use screenshots, and may she develop a commercial product? Provide a memorandum with thorough analysis and supporting research attached.

Figure 3. Complex Research Problem Needing Analysis

48. 1 OXford English Dictionary 433 (2d ed. 1989).

49. A Taxonomy for Learning, Teaching, and Assessing 271 fig.15.1 (2001) (reprinting the “expanded” skill-cycle from A.J. Romiszowski, Designing Instructional Systems: Decision MaKing in Course Planning and Curriculum Design 257 (1981)). 
Furthermore, the hallmark of good analysis is thoroughness. Often this is ensured by using a heuristic, a kind of schema that functions as an exhaustive checklist. For instance, students who engage in a "research interview," similar to a reference interview, would apply a heuristic ensuring a complete analysis of all of the parts. In this instance, the students would use table 5 to "work the problem." 50

\30 The ability to employ this heuristic as part of working the problem, like extracting terms for research, is an analytical skill. Using the heuristic, the attorney may identify research terms and issues as shown in figure 4. After the terms are identified, they need to be separated and organized in a manner that can facilitate orderly research. This can be seen in figure 5 .

I31 Separating the issues into manageable elements and organizing them so that general background knowledge precedes attempts to resolve narrower issues is key. Usually researchers will have to research general issues first, before recognizing and organizing narrower issues. Organization and moving to narrower and narrower issues constitutes the essence of analysis.

\32 This activity is identical to the "issue spotting" common to exams in most substantive law school courses. The difference is that those problems require reliance upon what a student has already learned through course readings and lectures, whereas in a research course, such problems require active learning in the

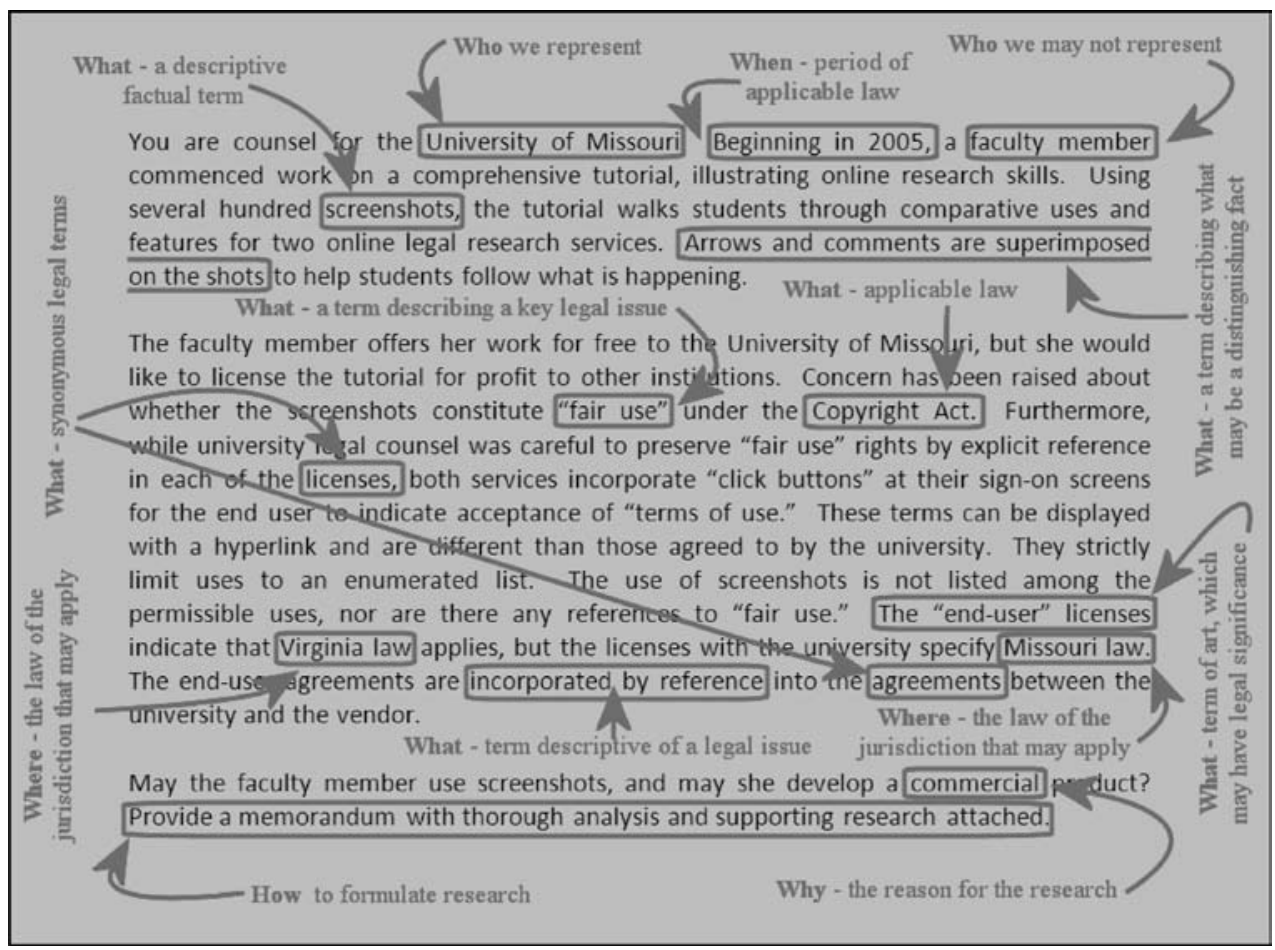

Figure 4. Possible Research Issues and Subject Descriptors Resulting from Analysis

50. See generally Paul D. Callister, Working the Problem, ILL. B.J., Jan. 2003, at 43; Callister, supra note 14, at 33-36. A version of table 5, focusing on a different legal issue, was published id. at 35. 


\section{Table 5}

\section{The Research Interview}

What You Need to Know

Parties

Descriptive Words of Facts or Terms of Art

Descriptive Words of Legal Issues

Specific Sources to Be Used

Applicable Jurisdictions

Time Periods

Time Deadlines/Priority

\section{Objective}

Precision/Recall

Billable Time/Costs

Presentations of Results and Reporting Back

\section{Sample Questions}

\section{Who?}

Who are we representing (i.e., which side of the issue are we on-buyer or seller, plaintiff or defendant, etc.)? What legal entities are involved (any trusts, corporations, partnerships, etc.)?

\section{What?}

Besides the term "incorporation by reference," are there other terms I should be using, like "modification" or "amendment"? I'm not sure if I understand the difference or if it matters. How else might a "screenshot" be described in the literature? Is "thumbnail image" a sufficiently analogous concept?

Do you think that the best subject heading to describe the problem is "copyright-transformative use"?

Is there any specific treatise or loose-leaf service I should consult in addition to Nimmer on Copyright?

Where?

Are there any choice-of-law or forum issues? Do you want me to research Virginia as well as Missouri licensing law? Do you want me to confine my federal copyright research to the Eighth Circuit?

\section{When?}

What time periods do you want me to research? Are the last two years sufficient? Does the time period (day, night, season, etc.) of any of the events in the case matter?

Do you want a quick answer or exhaustive research? If I complete this by Tuesday morning, is that okay?

\section{Why?}

What are we trying to accomplish with this memo, brief, motion, contract, etc.? How do we want this to come out?

\section{How?}

Do you want all of the relevant journal articles or just the best article on the topic? Do you want all of the cases dealing with transformative use and copyright or just two or three cases that bear the closest relationship to the issue of screenshots?

How long should this take me? Are billable hours limited? May I use LexisNexis or Westlaw? Which parts of the research, if any, would you do online? Do you want me to try to use free sources for my research? Has anyone ever done similar research on the topic that I should know about?

How do you want me to present my results? Do you just want printouts marked with highlighter or a full memo? Should I check back with my initial results before proceeding any further? 
- $\quad$ General: Fair Use Privilege under Copyright

○ Narrow: Does it cover "screen shots" as a "transformative use"?

- Narrower: Effect of added arrows and commentary

- Narrower: Number of slides

- Narrower: Commercial use

- Narrow: Does copyright law trump state contract law governing licenses?

- $\quad$ General: Electronic Licensing under State Law

○ Narrow: What law governs the license? Missouri v. Virginia?

- Narrower: Why did the vendors choose Virginia?

- Narrower: What kind of law for licensing might apply? UCC Article 2, UCC Article 2A, UCITA, or common law of contracts?

- Narrower: Assuming applicability of state law, what is the relationship of federal copyright to state contract law?

- Narrow: Enforceability of terms under state law

- Narrower: Incorporation by reference and manifestation of assent for amendment via end-user licenses

- Narrower: Void as against public policy or as unconscionable for eliminating fair use privileges under federal copyright law

Figure 5. Organized List of Possible Research Issues and Subject Descriptors

classroom $^{51}$ and lifelong learning after graduation. These are important valueadded justifications for inclusion of research courses and requirements in curriculum reform.

I33 Besides being the opposite of analysis, synthesis is defined as: “The putting together of parts or elements so as to make up a complex whole; the combination of immaterial or abstract things, or of elements into an ideal or abstract whole."52 In Romiszowski's "Expanded Skill-Cycle" it is described as the "ability to generate alternative solutions." 53 Per Bloom's Taxonomy, synthesis calls for "derivation of a set of abstract relations." ${ }^{4}$ To synthesize, the researcher moves beyond the parts of the problem and looks for relationships to other issues, resources, alternative scenarios for analysis, and possible options as solutions.

I34 For example, in the problem in figure 3, there is an important interrelationship between federal copyright law and state contract law. Federal copyright law

51. For a good overview of active learning in the context of legal education, see Gerald F. Hess, Principle 3: Good Practice Encourages Active Learning, 49 J. LEGAL EdUC. 401 (1999). For convincing criticism of the failure of "active learning," experiential, problem-based and other "minimallyguided" approaches to instruction, see Kirschner et al., supra note 32. Even though the image I've included of Bloom's Taxonomy is subtitled "Learning in Action," this article does not advocate a minimally-guided approach to learning. Rather, it advocates development of a taxonomy for guiding legal research instruction.

52. 17 OXford English Dictionary, supra note 48, at 488 (definition 6.a.).

53. RomiszowSKI, supra note 49 , at 257.

54. Unlike Bloom, I am deferring "production” of "unique communications” or "plans," which Bloom includes in Synthesis, to Resolve. See Krathwohl, supra note 34, at 213 tbl.1. 
may trump contract law, thereby upholding fair use privileges of the licensee, or on the other hand, a license governed by state law may mean that a licensee has "contracted away" his or her fair use privileges. Indeed, state contract law may also determine that modifications of a license by the end user do not bind the university or that provisions vitiating fair use privileges may be void as against public policy. It is through synthesis that the researcher determines that there are issues with respect to the relationship of each body of law to the other. Besides recognizing the relationships and resulting alternative scenarios for analysis, the expert researcher must produce recommendations or, in the taxonomy's technical jargon, "unique communications," to have fully engaged in synthesis.

I35 The best way to learn analysis and synthesis is through simulation under real practice conditions. The simulation is distinguishable from the next order in the taxonomy ("Resolve"), in that articulation of a solution to the problem is not as important as the repeated, iterative exposure to the processes of analysis and synthesis. For instance, analysis can be taught by having students repeatedly simulate, with some guidance, the extracting of terms and reorganization of the parts of a research problem, with feedback from the instructor. Synthesis also follows the "simulation" exercise, when students are asked to consider where the issues presented in the problem sit within a larger context, how the issues interact with one another, and what related legal subjects or issues should be considered.

I36 As another illustration, students could be asked to expand table 3 to include legislative and regulatory histories and case briefs, producing something like figure 6. The process of taking existing conceptual models for solving problems and expanding on them is a type of synthesis.

\section{Concluding}

I37 I again depart from Bloom, this time by classifying the fifth phase as Concluding. I might have used Production, one of Bloom's terms. However, even then, Bloom includes production as a part of synthesis, and I have separated it out, as the step following the analysis and synthesis in which the expert legal researcher reports back, producing a conclusion. After observing law students educated in foreign legal traditions, and after reading some of my American law students' papers, I am certain that reaching a conclusion is frequently an overlooked step, a separate type of learning, and not a foregone "conclusion" of having engaged in analysis and synthesis. Nor is reaching a conclusion necessarily relegated to the area of substantive law, for those who wish to maintain the distinction between substantive and practice skills. ${ }^{55}$

I38 In 2004, I participated in a conference in Prague on legal skills training as part of the ABA Central European and Eurasian Law Initiative. The frequent complaint made by law firms participating in the conference was the failure of young lawyers from Eastern Europe to reach conclusions. They were good at summarizing the law, but few would venture to state a conclusion that would be of any guidance

55. Educating Lawyers undermines the importance of this distinction, calling for an "integrative model" of legal education, with practice as one of its three facets. Sullivan ET AL., supra note 6, at 194. 


\section{LEGAL RESOURCES CONCEPTUAL FRAMEWORK}

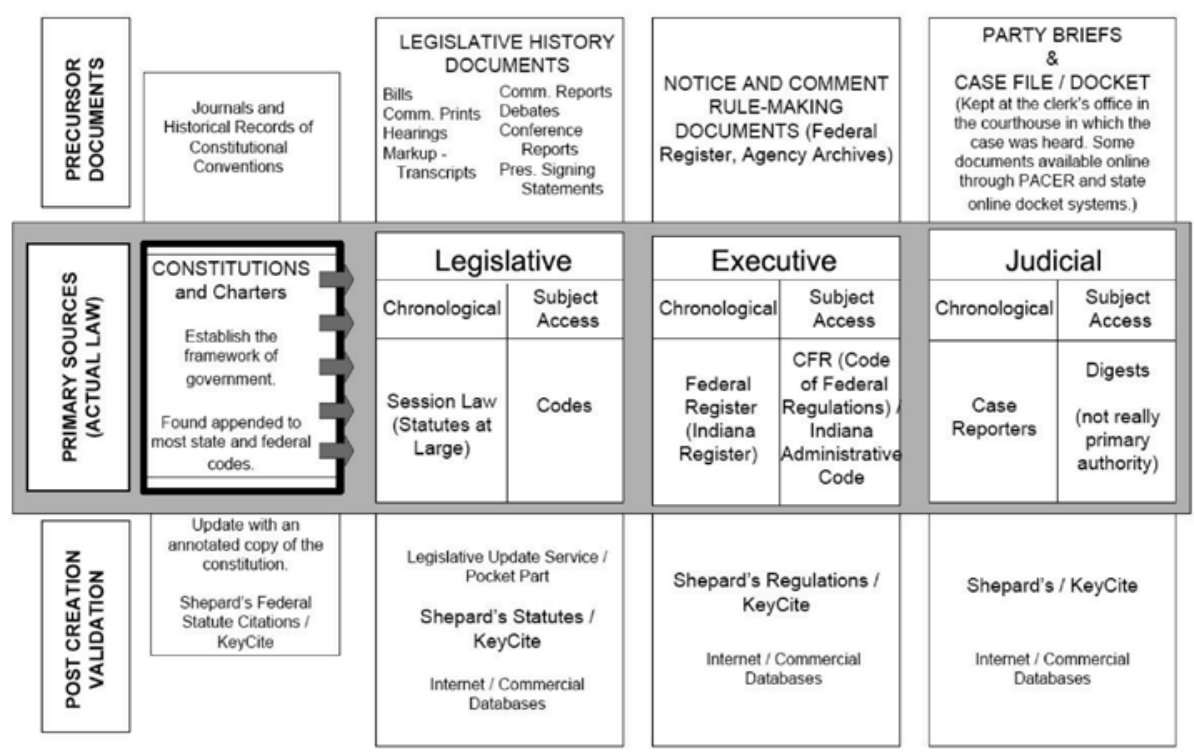

Figure 6. Modification of Wren Schema (see table 3) to Include Constitutions, Legislative History ("Precursor Documents"), and Citation Analysis ("Post Creation Validation")

to the client. Again, the point is that reaching a conclusion that is articulate and helpful is a skill to be mastered, but often overlooked.

\section{Metacognition}

I39 The final skill is Metacognition - the ability to assess, not only the result, but the schemata, including the processes, leading to the result. It is a kind of selfawareness and reflection of the research experience. ${ }^{56}$ For instance, the researcher should reflect upon whether he completed each step of the research process as shown in figure $7 .{ }^{57}$ The cycle is reiterative and the researcher should reflect upon whether new issues that arose as part of the research were pursued. Also, when the researcher discovered applicable cases, statutes, or regulations on point, did he make sure he understood the law as other professionals do, by consulting with

56. See How People Learn: Brain, Mind, Experience, and School, supra note 39, at 12 ("Metacognition refers to people's abilities to predict their performances on various tasks ... and to monitor their current levels of mastery and understanding.”).

57. The importance of guided "pathways," such as the research cycle, was pointed out by Kirschner et al., supra note 32, at 80-81 (discussing the use of "process worksheets" to guide instruction). 


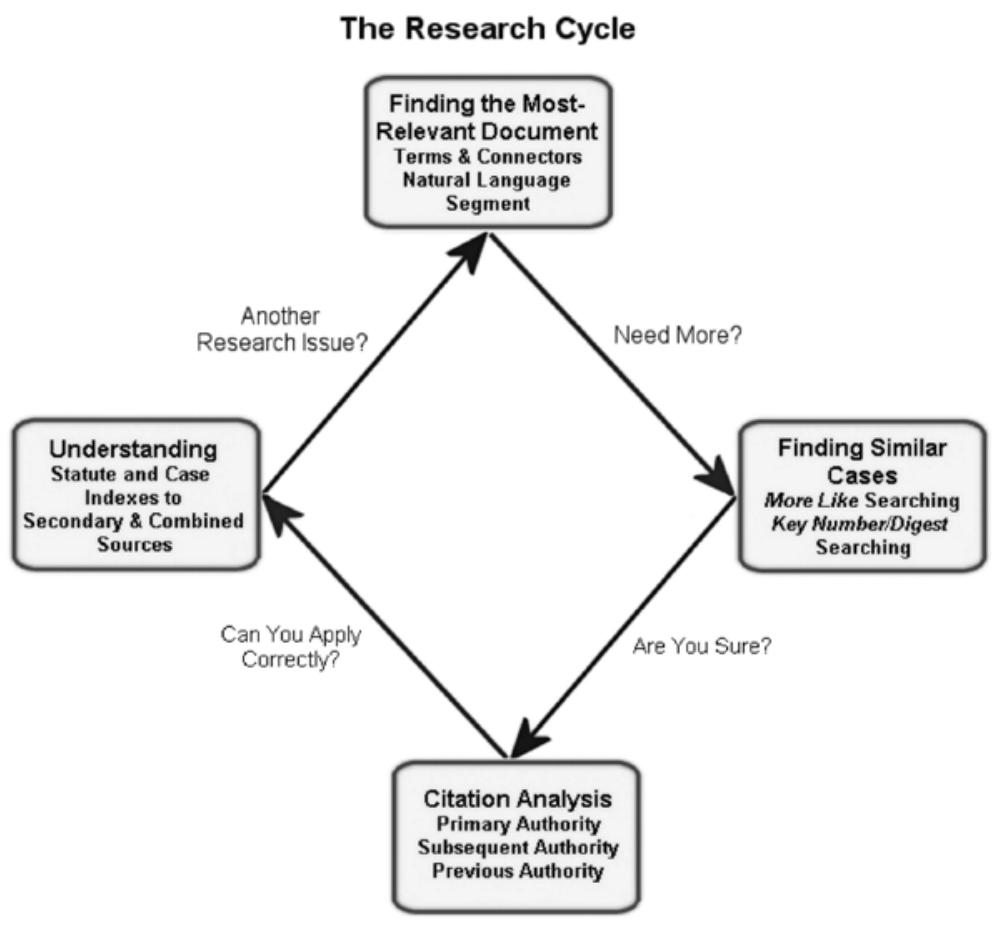

Figure 7. Reiterative Research Cycle

commentary? Did the process in figure 7 work? How might the process be modified to better suit the problem?

$\mathbb{T} 40$ Metacognition involves being explicit about the use of schemata, and constantly challenging whether they are applicable to experience. In science, Thomas Kuhn is associated with the "paradigm shift." ${ }^{58}$ In many ways, it is the essence of thinking.

I41 Put another way, metacognition is the distinction between training and education. A friend of mine who is an engineering fellow at Raytheon once insightfully observed about a plane crash: "The pilot and copilot did exactly what they were trained to do, but the plane crashed anyway because they failed to think ...." ${ }^{59}$ Etymologically, train and educate share similar meanings for their roots. ${ }^{60}$ However, I have found it useful to maintain a distinction between the two: training conditions the student to apply certain tools and methods to a particular type of problem, but education teaches the student to thoughtfully analyze the characteristics and nature of the problem at hand, to creatively use or even invent the most appro-

58. KuHN, supra note 21, at 150.

59. Statement by Tom Woodall, made in a conversation with the author (quoted in Callister, supra note 11 , at 7$)$.

60. The etymologies of educate and train respectively suggest "lead[ing] forth" and "draw[ing] along," and both do so with reference to animals. 5 OXFORD ENGLISH DiCTIONARY, supra note 48, at 73 ("educate"); 18 id. at 367 ("train"). 
priate technique in solving the problem, given one's understanding of the strengths and weaknesses of the various resources at hand. In the above example, the pilots followed procedures that they had learned by rote for dealing with a very specific range of problems. However, their failure to think through the problem before them, to challenge their training's schema, and to consider the appropriate plausible solutions, may have directly led to the loss of their aircraft and the lives of those onboard. ${ }^{61}$ The same is true of metacognition. If we simply train students with known problems and resources, they may fail entirely when facing the unknown.

\section{Application of the Adapted Taxonomy to Instruction and Assessment}

I42 Beyond the explanation of my Adapted Taxonomy, I provide here some examples of how to use the taxonomy for instruction and assessment:

Learning Type: Remembering

\section{Research Competencies}

Recall, recognize, or remember:

- Federal and State Primary Resources: statutory codes, session laws, uniform and model codes, legislative histories, court rules, case reporters, codified regulations, regulatory registers, digests, Words \& Phrases, and citators

- Secondary Resources: American Jurisprudence, Corpus Juris Secondum, appropriate state encyclopedia (e.g., California Jurisprudence), Restatements, law reviews and journals, bar journals and materials, treatises, and hornbooks

- Combined Resources: American Law Reports and loose-leafs

\section{Activities}

- Matching or multiple choice exercises to help establish initial recognition among resources and a simple heuristic for organizing them

- "Build your own library" exercise to help student recognize the "standard" resources they will be expected to use in practice in their field and jurisdiction. With a limited budget, students are asked to build a library. The assignment might require selection of materials commonly used by practitioners from Svengalis's Legal Information Buyer's Guide \& Reference Manual for the following types of resources:

- Flagship Service: A comprehensive service, often with both primary and secondary material (such as CCH's U.S. Federal Standard Tax Reporter or Nimmer on Copyright)

- Practitioner-Oriented Set: Sources that are commentary only, are written by practitioners, and cover a more narrow field (such as Taxation of Mining Operations) 
- Handbooks: Sources that are designed for quick reference (such as Proof of Facts, Attorneys Illustrated Medical Journal or the CCH U.S. Master Tax Guide)

- News: News and current awareness services such as BNA's U.S. Law Week or Electronic Commerce \& Law Report

- Annotated primary law: statutory and regulatory codes, with annotations.

- Rules: rules for courts and administrative tribunals

○ Citation service: KeyCite, Shepard's, or other citators

\section{Learning Type: Understanding}

\section{Research Competencies}

- Define, distinguish, and describe key research terminology and relationships: intermediated and disintermediated searches, terms and connectors search, natural language search, segment and field search, topic and key number search, headnotes, KeySearch, core concepts, core terms, "more like this" search, relevancy rank search, precision, recall, citation analysis, and Shepardizing

\section{Activities}

Compare and contrast:

- What is the difference between intermediated and disintermediated searching? Answer: Intermediated searches involve human editors, indexers, catalogers, etc.

- How does searching topics and key numbers work? How does it differ from KeySearch? Answer: the West Key Number System is a taxonomy maintained by West editors, who group cases with similar points under the same topics and key numbers of over 100,000 classes and sub classes. It is an intermediated service. KeySearch tries to approximate a key number search by use of "pre-packaged" searches created by West editors. It is designed to be used with both headnoted cases and nonheadnoted materials. Although an electronic search, it is intermediated by West editors.

- How are "Core Terms" produced by LexisNexis, how are they different from West's Key Number System, and how are they useful? Answer: The terms are generated by computer algorithm and are supposed to be the most descriptive of its content. It is an alternative to searching using a human intermediated service such as West's Key Number System. It is an excellent way to search cases that are not "digested" in West's Key Number System (like cases in the Tax Court).

- How are the results from a terms and connectors search different from a relevancy-ranked natural language search? Answer: Terms and connectors produce every document in the database described by the terms in the search. All terms in the description of the search are given equal weight. In contrast, a natural language search reshuffles the 
entire database, like a deck of cards, with the most relevant document on top. Terms have different weight according to their rarity in the database as a whole, their repetition in the query, and their proximity to one another.

- What kind of search is LexisNexis's "More Like This"? Intermediated or disintermediated? Answer: It is a disintermediated search, based upon a natural language algorithm. The most relevant documents should appear at the top of the search results.

\section{Learning Type: Application}

\section{Research Competencies}

Exercise schemata:

- Working the Problem Schemata: Who, What, Where, When, Why, and How; ${ }^{62}$ Problem Typing ${ }^{63}$

- Resource Mapping: Primary, Secondary, and Combined Resources; ${ }^{64}$ Modified Wren Schema; ${ }^{65}$ Practice Library Checklist ${ }^{66}$

- Matching Problems to Resources: Legal Research Octants; ${ }^{67}$ computer algorithm vs. controlled vocabulary searching; natural language vs. terms and connectors; recall vs. precision searches ${ }^{68}$

- Processes: Legal Research Cycle; ${ }^{69}$ finding the best document; ${ }^{70}$ finding similar documents; ${ }^{71}$ stream of precedent; ${ }^{72}$ legislative process $^{73}$

62. See supra table 5.

63. See supra table 4.

64. See Paul D. Callister, Thinking about Legal Research Problems, Determine Whether Primary, Secondary or Combined Sources are Most Appropriate, http://www1.law.umkc.edu/faculty/callister/ bootcamp/Survival/Tab3.html (last updated July 1, 2009).

65. See supra table 3 and figure 6.

66. See, e.g., Paul D. Callister, PowerPoint Presentation, Federal Tax Hierarchies \& Transactional Law (2009), slides 16-27, available at http://www1.law.umkc.edu/faculty/callister/TAX/tax.ppt (illustrating classification of tax law resources needed for a practitioner's library).

67. See Paul D. Callister, Thinking about Legal Research Problems, Putting it All Together for Known Item and Subject Searches-The Octants of Legal Research, http://wwwl.law.umkc.edu/ faculty/callister/bootcamp/Survival/Tab5.html (last updated July 1, 2009).

68. See Paul D. Callister, Thinking about Legal Research Problems, Understanding Precision and Recall, http://www1.law.umkc.edu/faculty/callister/bootcamp/Survival/Precision1.html (last updated July 1, 2009).

69. See supra figure 7.

70. Paul D. Callister, PowerPoint Presentation, Finding the Best Document (2004), available at http://www1.law.umkc.edu/faculty/callister/bootcamp/ppt/MostRelevant_files/frame.htm.

71. See Paul D. Callister, Thinking about Legal Research Problems, Being Thorough: Finding Similar Cases, http://www1.law.umkc.edu/faculty/callister/bootcamp/Survival/Tab6More.html (last updated July 1, 2009).

72. See Paul D. Callister, Thinking about Legal Research Problems, Being Thorough: Citation Analysis, http://www1.law.umkc.edu/faculty/callister/bootcamp/Survival/Tab6Citation.html (last updated July 1, 2009).

73. See Hook, supra note 28 , at 254, fig.1. 


\section{Activities}

- Simulation of a series of short research interviews that require application of the schema in table 5. For example, the instructor plays the role of a supervising attorney who tends not to give out all of the information needed to solve a research question, unless the student (playing the associate) uses good interviewing techniques. The supervising attorney may fail to volunteer information about specific resources, particular topic headings for technical issues, varying expectations for the precision and recall of the search result, and unique requirements for presenting research findings. It is not necessary that students research the problem, but that they drill in a series of these interviews.

- Mapping exercise using a blank table 3 and requring filling in all of the catagories (cells) for case, statutory, and regulatory law for a particular state. The exercise could use a physical table or space with lines on it to permit tactile experience in handling and placing books within the correct catagories.

- A three-dimensional mapping exercise where students determine where various resources, for instance a print case law digest, would fall within a three-dimensional map of legal resources with the following axes: primary vs. secondary resources; chronological vs. subject organization; intermediated (controlled vocabulary) vs. distermediated resources (algorithmic). ${ }^{74}$

Answer: A print case digest falls into an octant in the three-dimensional space defined along the various axes as primary law, subject organization, intermediated. The case summaries of digests provide access to primary law, organized by subjects, which are created (intermediated) by human beings using controlled vocabularies.

- Using the octants model, what resource octant might be best to find the California murder case involving a defendant who beat up his girlfriend and in which the court ruled that a fetus is not a human being? Answer: As a general rule of thumb, the research should begin with resources in the primary, chronological, disintermediated (algorythmic) octant. The fact-specific nature of the inquiry is crying out for electronic "terms \& connectors" searching in a database of California case law.

- Where would a print case law digest find its best use in the research cycle described in figure 7 ?

Answer: Students can use case law digests after finding the best case on point (step one in the cycle) to look up the best topic and key number for the part of the decision corresponding to the issue being researched. The students may have found the best case match by a terms and connectors search, but then, as in step two in the cycle, they can find similar precedent and authority through intermediated tools-i.e., by 
following the topic and key number (electronically or in print) to other case law with the same topic and key number for similar points of law.

- For a single case, have students apply the "Stream of Precedent" schema to identify the major cases (including cases cited in the table of authorities) to develop a point of law, and check their status. For example, can students determine the status of laws enforcing the prohibition of polygamy by using this technique to look at Davis $v$. Beason ${ }^{75}$ Is polygamy still illegal?

Answer: KeyCite and Shepard's both treat Davis v. Beason with red caution signs because of the Supreme Court's ruling in Romer $v$. Evans, ${ }^{76}$ but only as to a single point of law regarding disenfranchisement based upon religious belief. The two services also note that Reynolds v. United States, ${ }^{77}$ one of two cases cited in Davis v. Beason, is no longer good law. The interesting point is that Shepard's gives Reynolds (the Supreme Court case upholding anti-polygamy statutes) a red stop sign, and KeyCite only gives it a yellow caution flag. Somewhat bizarrely, the court that Shepard's identifies as declaring the Supreme Court case to have been overruled is the Second Circuit Court of Appeals in Patrick v. LeFevre. ${ }^{78}$ By looking at the stream of precedent surrounding Davis v. Beason, students can more readily move onto analysis, and grasp that not only is Beason overruled with respect to anti-polygamy disenfranchisement laws, but that the foundation of Davis v. Beason (i.e., Reynolds v. United States) is suspect with respect to a different, but related, point of law.

Learning Type: Analysis/Synthesis

\section{Research Competency}

- Simulate analysis and synthesis on both simple and complex problems in a simulated practice evironment

\section{Activities}

- Have students engage in a whole-scale simulation of an assignment that requires them to put all of the schema together. The assignment may involve a variety of problem types and multiple research issuesan assignment that requires them not only to break down the various issues, but to understand the relationship between the issues, and alternative solutions or arguments. Ideally, students would start with the research interview, identify several problem types, draw upon their own conceptual map of legal research resources and pass through each 
step of the research cycle. While they may have mastered many of these skills in isolation, putting them all together in the face of a challenging problem is a new skill in and of itself.

For example, if the students were challenged with a problem like that in figure 3, they should have to first extract the problem in a research interview, work through identifying terms, decide what issues and areas of law are involved, what problem types present themselves, what the appropriate resources are based upon their understanding of the research terrain, and finally pass through every step of the research cycle. The problem in figure 3 also provides the advantage of requiring research in at least two areas of law-copyright and contract law (including drawing upon UCC Article 2, UCITA, and common law). (See figure 4 for illustration of the issues.) The issues in the problem require reasoning by analogy (a type of synthesis) from several bodies of laws, as well as analytical separation of the various issues for research purposes.

\section{Learning Type: Concluding}

\section{Research Competency}

- Resolve a problem and report a conclusion that takes a position as informed by research

\section{Activities}

- Research memoranda, pathfinders, and academic papers are all proper outputs for "concluding"

- To a large extent, pathfinders have the advantage of isolating research from writing (ensuring that attention is given to research), but the disadvanatage of not simulating the law practice environment and not integrating research with writing, which is often an iterative process

\section{Learning Type: Metacognition}

\section{Research Competencies}

- Reflection on and assessment of research experiences and the ability to critique, modify, and invent research schema

\section{Activities}

- Projects requiring reiterative research are excellent activities for honing metacognition because researchers must constantly follow up on new issues or refine old ones, provided that students periodically stop and assess where they are in the process, what is working, and what is not working

- Group presentations of research, including the process by which students obtained results, followed by criticism, can serve as an effective catalyst for metacognition 
- Reflection essays are a frequently used tool and can be adapted for use as research logs or diaries to help cultivate metacognition

- Perhaps most important, exercises in the express recognition, modification, and invention of schema for working research problems, recognizing and catagorizing research resources, and understanding the research process serve as the capstone of legal research skills. For example, one exercise might be to create a heuristic for conducting competitive business intelligence or citation analysis and then have class members compare their checklists.

I43 The above is meant to be a means to describe the learning activities, assignments, and forms assessments I would need to bring into a general course on legal research. It is the beginning of a syllabus. Its function in this article is to demonstrate the application of an adapted Bloom's Taxonomy. Like my version of Bloom's Taxonomy, it is only a suggestion, and hopefully a source of motivation, for others to apply Bloom to create their own tables for their courses.

\section{In Conclusion: It Is Time to Bloom}

I44 Our profession lacks sufficient pedagogy, both theory and methodology based on such theory. In this article, I have surveyed our literature, questioning whether there is lack of sufficient dialogue and meager representation of pedagogy as developed in other fields. After explaining Bloom's Taxonomy, I proposed an adapted version, in skeletal form, following it with discussion of the various elements, and finally, I offered an illustration of the taxonomy's practical application for instructional design in legal research courses.

II45 Notwithstanding my efforts, my greatest fear is that I have gone too far. I may have suggested too much. What is needed is a collaborative effort, a response to the Carnegie Foundation report. After the MacCrate Report, AALL produced Core Legal Research Competencies. Now, we need another collaborative response, but this time based upon the theories and resulting methodologies of the leading pedagogues from outside our narrow field.

I46 It is a season to blossom. It is a day for our profession to rise to the challenge of Curriculum 2.0, to demonstrate our ability to collaborate (already much noted in interlibrary loan and professional service), and to invigorate our intellectual roots with new and better scholarship. To that end, let us earnestly begin. 


\section{Appendix}

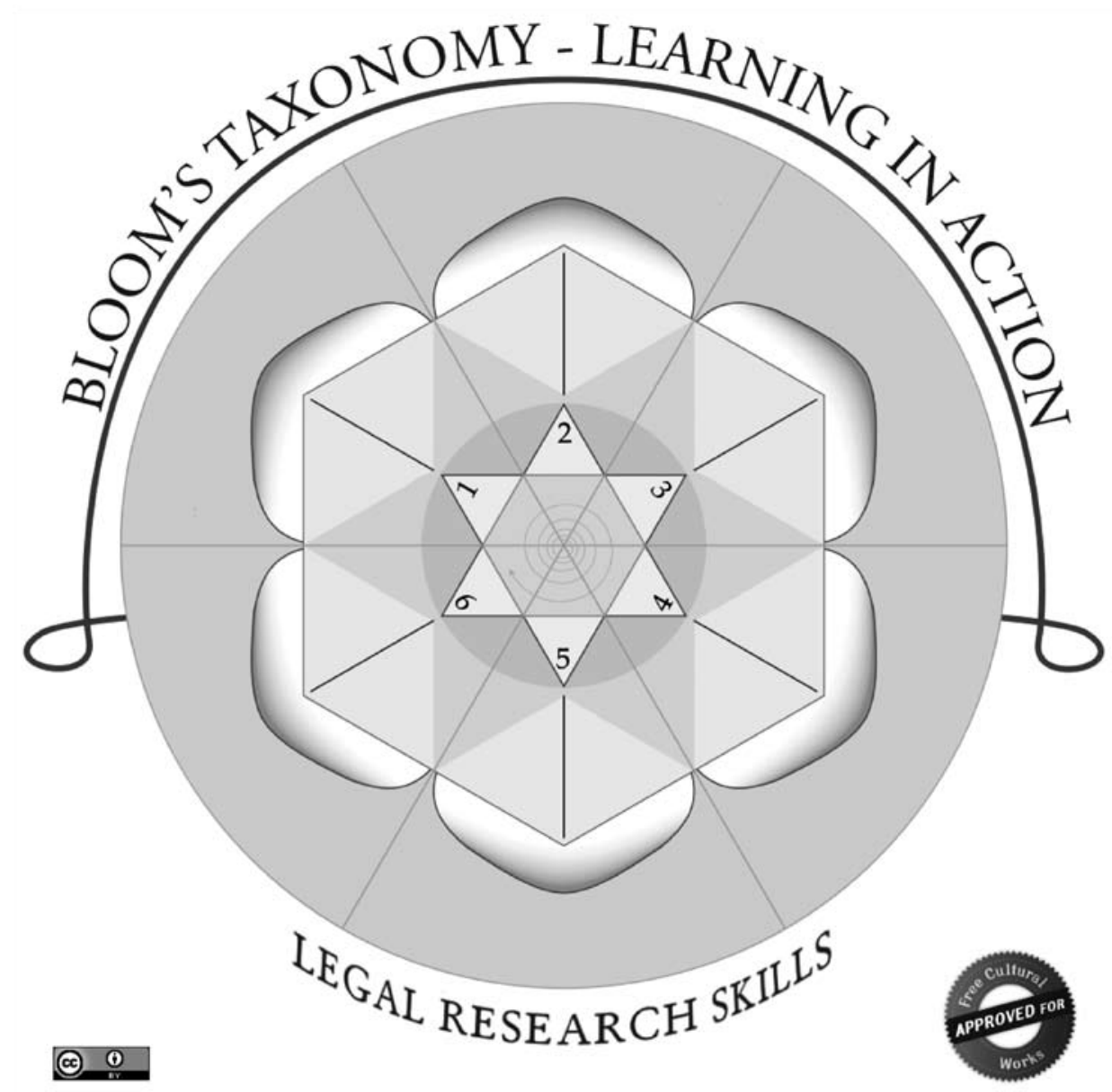

Figure 8. Blank Bloom's Taxonomy for Individual Use

Image is licensed under the same terms and conditions as the original as updated by Creative Commons License BY 3.o. For terms of license, see http://creativecommons.org/licenses/by/3.o/. 